
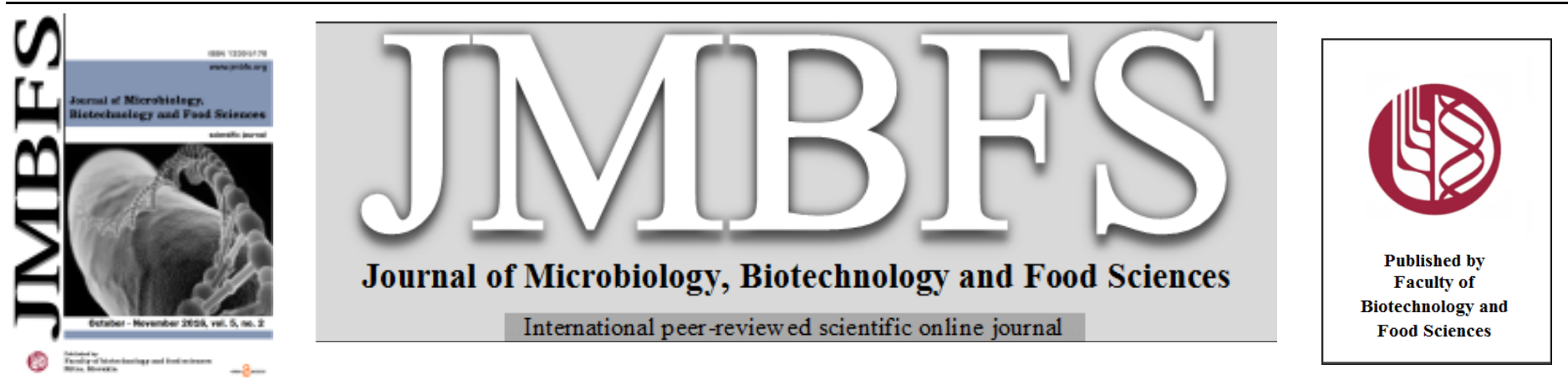

\title{
WASTE BIODEGRADATION AND UTILIZATION BY PSEUDOMONAS SPECIES
}

\author{
Victoria Savich, Galina Novik*
}

\section{Address(es):}

Institute of Microbiology, National Academy of Sciences of Belarus, Kuprevich 2, 220141 Minsk, Republic of Belarus, Tel.: +375 17 2686121, Fax: +375 172674766

*Corresponding author: galina_novik@mbio.bas-net.by

doi: 10.15414/jmbfs.2016.6.2.851-857

\section{ARTICLE INFO}

Received 29. 4. 2016

Revised 8. 6. 2016

Accepted 30. 7. 2016

Published 3. 10. 2016

Review

open 2 access

\begin{abstract}
Waste utilization is the global problem of modern society. Waste products display negative influence on environment and human health for a long time, consequently different methods have been developed for waste disposal. They include application of physical, chemical and biological degradation. Special interest is induced by using microbial cultures such as Pseudomonas. The article considers Pseudomonas genus as the effective key to the solution of relevant problem lifting adverse effects of toxic by-products. The studies revealed that pseudomonades due to metabolic and physiological diversity are able to degrade a wide range of compounds hazardous to living organisms. Indeed, during biodegradation bacteria produce secondary metabolites that can be used in medicine, industry, agriculture and bioremediation. Waste serves in this case as a cheap source of carbon and nitrogen. The genus possesses vast potential in both tackling contamination problems and production of valuable compounds for numerous applications.
\end{abstract}

Keywords: Pseudomonas; waste; biodegradation; utilization; biosynthesis

\section{INTRODUCTION}

Waste management is a worldwide challenge urging effective solution strategy. Waste can cause deleterious impact on human health and condition of environment. About $85 \%$ of various wastes are produced in USA, Europe and Oceania. These materials are discharged in amount $1.6 \mathrm{~kg}$ per capita in USA, 1.5 $\mathrm{kg}$ in Europe, $0.8 \mathrm{~kg}$ in Oceania and $0.4 \mathrm{~kg}$ in Asia (Williams, 2005). There are several approaches to solve the problem, including recycling and utilization. Recycling can occur by different ways via physical, chemical and biological degradation.

On the other hand, genus Pseudomonas is known for its ability to utilize a large variety of compounds and produce a wide range of secondary metabolites and biopolymers owing to metabolic and physiological diversity. Using industrial, agricultural and household wastes as media for biodegradation or production of various compounds is becoming more attractive. Several studies indicated favorable application prospects of this genus.

\section{METABOLIC PROCESSES IN PSEUDOMONAS}

\section{Catabolic pathways of Pseudomonas}

Pseudomonas species include bacteria inhabiting various ecological niches Pseudomonades are able to live in both simple and complex media utilizing many compounds as substrates owing to the nutritional versatility. The variety is provided by diverse metabolic pathways observed in these bacteria. These biochemical routes allow to degrade a wide spectrum of substances, including toxic ones to other prokaryotes and to higher organisms. The breakdown of various compounds makes Pseudomonas most appropriate in biodegradation of waste, especially persistent components.

Petroleum and its fractions consist of several classes of compounds (mainly hydrocarbons): saturates, aromatics, other organic chemicals containing nitrogen, oxygen, sulfur, and traces of metals. The saturates include normal alkanes, branched alkanes, and cycloalkanes called paraffins, isoparaffins, and naphthenes, respectively. Normal and branched alkanes have the general formula $\mathrm{C}_{\mathrm{n}} \mathrm{H}_{2 \mathrm{n}+2}$, with $\mathrm{n}$ usually ranging from 1 to 40 . Cycloalkanes are distinguished by one or more carbon rings to which hydrogen atoms are attached according to the formula $\mathrm{C}_{\mathrm{n}} \mathrm{H}_{2 \mathrm{n}}$ while aromatic compounds contain one or more aromatic rings These are major constituents of petroleum (National Research Council, 1985; Robbins and Hsu, 2000). Hydrocarbon components may turn out to be carcinogens or organic pollutants, hence bioremediation is considered as effective solution of the problem.

Alkane utilization via oxidation to 1-alkanols (terminal oxidation) has been described for Pseudomonas. Enzymatic system involved in oxidation consists of three components: a particulate hydroxylase (EC 1.14.15.3) and two soluble proteins, rubredoxin and rubredoxin reductase (EC 1.18.1.1), mediating electron transfer between $\mathrm{NADH}$ and the hydroxylase. The product of the alkane hydroxylase reaction further acts as substrate for alcohol- (EC 1.1.1.1) and aldehyde dehydrogenases (EC 1.2.1.5) converting 1-alkanol to fatty acids. They are degraded by $\beta$-oxidation to acetyl-CoA, which enters the central metabolism, or poly-(3-hydroxyalkanoate) generated under nitrogen or phosphorous limitation. Alternative pathway for alkane utilization (subterminal oxidation) produces secondary alcohol that can be converted into ketone. The latter is oxidized to ester which in turn is hydrolyzed by esterase (EC 3.1.2.2) to an alcohol and fatty acid (Ramos, 2004).

Branched alkanes are more recalcitrant to degradation than linear because of methyl branching obstructing access of enzymes. However, some investigations in this direction were carried out. Mutants of $P$. citronellolis were able to grow on 2,6-dimethyloctane via a combination of alkane and citronellol degradative pathways (Fall et al., 1979). 2-methylhexane maybe be decomposed to 5methylhexanoic and iso-valeric acid accompanied by the second pathway via 2 methylhexanoic acid (Thijsse and Van der Linden, 1961).

Degradation of cyclic alkanes also has been studied. The formation of valeric acid, formic acid, cyclohexanol and hexanedioic acid from cyclohexane by Pseudomonas was reported (Imelik, 1948). Other researchers showed that hydroxylase system of microbial cells transformed cycloalkanes into cycloalkanols as the reaction products (van Beilen et al., 1994; van Ravenswaay Claasen and Van der Linden, 1971). Cyclohexanol was further degraded via cyclohexanone and $\varepsilon$-caprolactone to adipic acid (Anderson et al., 1980).

Pseudomonas strains are able to degrade a number of aromatic compounds from various sources, including petroleum and dyes. So far 11 central catabolic pathways with many different peripheral pathways have been revealed. By-paths split substrates into a few intermediates (usually dihydroxybenzenes or dihydroxyaromatic acids), which are then ring-cleaved and converted to tricarboxylic acid cycle intermediates through the corresponding central pathways (Timmis, 2010). There are many studies related to aromatic catabolic pathways of Pseudomonas, so we'll concentrate on degradation of caffeine and nicotine.

Several biochemical routes of nicotine utilization by microorganisms were detected: pyridine, pyrrolidine and demethylation pathways. The attack of 
nicotine molecule at the pyrrolidine ring is typical for Pseudomonas genus (Brandsch, 2006). However, this pathway varies in different strains. Nicotine degradation by $P$. putida S16 starts via oxidation with the formation of methylmyosmine, which, upon addition of water, spontaneously leads to ring opening and formation of pseudooxynicotine. Subsequent steps are the formation of 3-succinoylpyridine (SP) after removal of methylamine and hydroxylation of the pyridine ring at position 6 with generation of 6-hydroxy-3-succinoylpyridine (HSP) followed by an oxidative decarboxylation to 2,5-dihydroxypyridine (DHP) and succinate. DHP is further degraded into lactic and 3-hydroxybutyric acids (Brandsch, 2006; Wang et al., 2007). Formation of HSP from nicotine by Pseudomonas sp. HZN6 is controlled by the similar mechanism, however, pseudooxynicotine at first is transformed into 3-succinoylsemialdehyde-pyridine and then into SP (Qiu et al., 2012). Pseudomonas sp. CS possesses both pyrrolidine and demethylation pathways. The strain is able to provide direct demethylation to form 3-(3,4-dihydro-2 $H$-pyrrol-5-yl) pyridine, and hydroxylation at position 2 of pyrrolidine ring to yield 1-methyl-5-(3-pyridyl) pyrrolidine-2-ol, later converted to cotinine (Wang et al., 2012). Pseudomona sp. Nic22 generates a wide spectrum of intermediates, including hazardous compounds such as myosmine (3-(4,5-dihydro-3H-pyrrol-2- yl)pyridine), 2,3' dipyridyl and cotinine, further subject to complete degradation (Chen et al. 2008). $P$. geniculata $\mathrm{N} 1$ can decompose nicotine with formation of 6 hydroxynicotine, 6-hydroxy- $N$-methylmyosmine, 6-hydroxy-pseudooxynicotine, 2,6-dihydroxypseudooxynicotine, myosmine and cotinine (Liu et al., 2014) Another nicotine degradation pathway was established for $P$. plecoglossicida TND35. The strain provided for the oxidation of the pyrrolidine ring to $N$ methylmyosmine. This intermediate was further hydroxylated at 2 nd position of pyrrolidine ring to form cotinine analogue, 2,3-dihydro-1-methyl-5-(pyridin-3yl)- $1 H$-pyrrol-2-ol. The metabolite can be demethylated and oxidized to another cotinine analogue, 5-(pyridin-3-yl)-1H-pyrrol-2(3H)-one, or oxidized and released methylamine, that leads to the pyrrolidine ring opening to form an end product 4-hydroxy-1-(3-pyridyl)-1-butanone. Additionally, the strain is able to disrupt bond between pyridine and pyrrolidine ring of the nicotine molecule, forming 3,5-bis(1-methylpyrrolidin-2-yl) (Raman et al., 2014). Thus the transformation of nicotine by Pseudomonas can proceed along differen metabolic pathways with formation of a wide range of compounds, hence new variations of nicotine degradation can be expected.

Bacteria utilize caffeine via two catabolic pathways: $N$-demethylation and $\mathrm{C}-8$ oxidation. The N-demethylation pathway is the most common, detected in ove $80 \%$ of reported isolates, including Pseudomonas. During degradation each of the three methyl groups of caffeine (1,3,7-trimethylxanthine) was removed in series, molecular oxygen was incorporated and formaldehyde and water molecule were produced. At the first step theobromine (3,7-dimethylxanthine) is mainly formed with small amounts of paraxanthine (1,7-dimethylxanthine) for some strains. Later theobromine or paraxanthine are $N$-demethylated to form 7-methylxanthine converted into xanthine. Then uric acid produced from xanthine enters norma purine catabolic pathway (Summers et al., 2015). Additionally, P. putida CBB5 was reported to degrade theophylline (1,3-dimethylxanthine), 3-methylxanthine and 1-methylxanthine (products of other variant of $\mathrm{N}$-demethylation pathway) to xanthine. The strain also oxidized these compounds to 1,3-dimethyluric, 1- and 3 methyluric acids - terminal metabolites of CBB5 (Yu et al., 2009).

Plastics are mainly represented by organic polymers of high molecular weight. They are generally not biodegradable and arouse pollution problem. Plastics are utilized in the course of several stages: biodeterioration, depolymerisation, assimilation and mineralization. During biodeterioration bacteria split materials into tiny fractions. Depolymerisation is cleavage of polymeric molecules into oligomers, dimers and monomers. Assimilation is integration of intermediates into microbial metabolism and finally mineralization releases simple molecules, like $\mathrm{CO}_{2}, \mathrm{~N}_{2}, \mathrm{CH}_{4}, \mathrm{H}_{2} \mathrm{O}$ and different salts in the environment. The biodegradation process can stop at each stage (Lucas et al., 2008). The investigation concerning plastic decay is under way and some examples are mentioned below in other chapters. However, there is a lot of work for researchers, especially concerning utilization of resistant polymers. Some examples of plastic degradation are mentioned below.

On the other hand, degradation of natural polymers such as chitin is a more studied topic. Chitin is widespread in nature as a structural element in many organisms, e.g., fungi, crustaceans, insects or algae. This compound consists of $(1 \rightarrow 4)$ - $\beta$-linked N-acetyl-D-glucosamine. The single sugar units are rotated $180^{\circ}$ to each other, with the disaccharide $\mathrm{N}, \mathrm{N}^{\prime}$-diacetylchitobiose as the structural subunit. Chitin is classified into three different crystalline forms: $\alpha-, \beta-$, and $\gamma$, differing in the orientation of micro-fibrils. Chitin usually is associated with other adjacent structural polymers such as proteins or glucans, which often contribute more than $50 \%$ of the total chitin-containing tissue. The polymer can be degraded via two pathways: the $(1 \rightarrow 4)-\beta$-glycoside bond is exposed to hydrolysis or the compound is deacetylated to chitosan or possibly even cellulose-like forms after additional deamination. Further intermediates can be reintegrated into cell material or mineralized and removed from the system (Beier and Bertilsson, 2014). Research showed that Pseudomonas is able to convert chitin into chitosan (Ghorbell-Bellaaj et al., 2012).

Thus genus Pseudomonas possesses various metabolic pathways. They engage numerous compounds as sources of valuable nutrients (e.g. essential amino acids from keratin) (Chaturvedi and Verma, 2014) and even degrade toxic chemicals, like free cyanide and thiocyanate by hydrolytic mechanism, resulting in accumulation of ammonium in the medium (Mekuto et al., 2016). Metabolic diversity provides vast opportunities for Pseudomonas application in waste disposal.

\section{Biosynthesis of biosurfactants and polyhydroxyalkanoates}

Pseudomonas is able either to degrade waste and its components or utilize it for biosynthesis of valuable products. The genus produces a wide range of substances, however, many studies related to waste disposal deal with biosurfactants (mainly rhamnolipids) and polyhydroxyalkanoates (PHAs). The corresponding biosynthetic pathways were thoroughly investigated for Pseudomonas genus.

Biosurfactants are the surface-active agents capable of reducing surface and interfacial tension between liquids, solids and gases and they find use in cosmetic, food, petroleum industries, medicine and bioremediation. These compounds are non-toxic and biodegradable in contrast to chemical analogs (Chamy and Rosenkranz, 2013). Biosurfactants are usually glycolipids, composed of carbohydrates in combination with long-chain aliphatic acids or hydroxyaliphatic acids. Formation of mono and di-rhamnolipids is mediated by rhamnosyltransferase I and II (EC 2.4.1.-), respectively. Two quorum sensing systems (QSS) are involved in regulatory mechanisms of rhamnolipid synthesis. In the first QSS genes $r h l A$ and $r h l B$ encoding rhamnosyltransferase I are positively regulated by rhlR (transcriptional activator). The latter and autoinducer are encoded by rhlR and rhlI, respectively. Two signal molecules, N-butanoyl-Lhomoserine (PAI-2) and hexanoyl-L-homoserine lactone are produced by rhll. Transcriptional activator binds to autoinducer PAI-2 and this complex causes activation of rhlA and $r h l B$. The second QSS containing two genes (lasR and lasI) positively regulates the transcription of $r h l R$ system. Rhamnosyltransferase I catalyses the synthesis of mono-rhamnolipid from deoxythymidine-diphospho-Lrhamnose (dTDP-L-rhamnose) and $\beta$-hydroxydecanoyl- $\beta$-hydroxydecanoate. Dirhamnolipid is produced from mono-rhamnolipid and dTDP-L-rhamnose (Satpute et al., 2010).

PHAs, like biosurfactants are characterized by low toxicity and biodegradability and can be used in the packaging, pharmaceutical, food industries, agriculture and medicine. PHAs are composed of medium-chain length $(R)$-3-hydroxyfatty acids (6-14 carbon atoms). There are several metabolic pathways of biosynthesis depending on the carbon source. If cells utilize fatty acids, the latter are converted to $(R)$-3-hydroxyacyl-CoA via $\beta$-oxidation pathway. Then PHA synthase (EC 2.3.1.B3) catalyzes the enantioselective polymerization of $(R)-3$ hydroxyacyl-CoA to PHA. If the carbon source is oxidized to acetyl-CoA, the intermediates of fatty acid biosynthesis are formed de novo (Ramos, 2004; Rehm, 2008)

\section{APPLICATIONS OF PSEUDOMONAS IN WASTE BIODEGRADATION}

Plastics are the common compounds replacing traditional materials in diverse fields. Most plastic products are resistant to biodegradation and can display toxic properties threatening the environment and human health. However, the same synthetic polymers may be degraded by bacteria including pseudomonades. An example is polyvinyl alcohol (PVA) that is widely used in adhesive, papercoating and textile industries and detected in wastewater (Chen et al., 2007, Chiellini et al., 2006). Experiments revealed that $P$. alcaligenes can reduce the pollution caused by PVA-based materials. However, elevated rate of degradation was achieved when PVA concentration was low, $\mathrm{pH}$ was alkaline, the inoculum size was large and minimum flow rate was maintained. Nevertheless, the strain demonstrated effective degradation of PVA (Bharathiraja et al., 2013) Decomposing potential of different Pseudomonas strains was compared in experiments with low density polyethylene (LDPE) used widely as packaging material. After 120 days of incubation, the extent of weight reduction was $20 \%$ for $P$. aeruginosa (PAO1), $11 \%$ for $P$. aeruginosa (ATCC), $9 \%$ for $P$. putida $11.3 \%$ for $P$. syringae strains, $0.3 \%$ for the negative control. Maximum fall in tensile strength and carbonyl index was reached by PAO1. The degradation products comprise long chain fatty acids, esters, hydrocarbons, oxygenated chemical compounds predominantly containing aldehydes, ketones, ester and ether groups, unsaturated fatty acids, etc. (Kyaw et al., 2012). Other reports are focused on biodegradation of resistant polymers. Some bacterial strains are able to decompose these compounds. P. aeruginosa strain HE858284 was confirmed to partially degrade the recalcitrant nylon-6 polymer to 6-aminohexanoic acid, $\varepsilon$ caprolactam and some unidentified oligomers (Sanuth et al., 2015).

Biodegradation of caffeine is also a possible application for Pseudomonas Caffeine is used in food industry and medicine, however, its production yields annually nearly two million tons of residues in the form of pulp, husk, spent grounds and residual water. These wastes are rich in carbohydrates, proteins and minerals, but also contain toxic compounds such as tannins, polyphenols, and caffeine that can be toxic in elevated concentrations to saprophytic organisms involved in biotransformation processes in the environment. Nevertheless, several microorganisms, including Pseudomonas strains are able to utilize caffeine. Pseudomonas sp. NCIM 5235 can completely degrade $1.2 \mathrm{~g} / \mathrm{L}$ and $5 \mathrm{~g} / \mathrm{L}$ 
of caffeine in 15 and $48 \mathrm{~h}$, respectively. The isolate also broke down 59.9 and $21.5 \%$ of caffeine in $96 \mathrm{~h}$ when initial concentration of caffeine in the medium was 7.5 and $10 \mathrm{~g} / \mathrm{L}$, respectively. Decomposition of caffeine occurred via demethylation. By $24 \mathrm{~h}$ both 3,7-dimethylxanthine at concentration $0.28 \mathrm{~g} / \mathrm{L}$ and 7-methylxanthine at concentration $0.37 \mathrm{~g} / \mathrm{L}$ were formed when initial concentration of caffeine was $5 \mathrm{~g} / \mathrm{L}$. By $48 \mathrm{~h}$ the level of 3,7-dimethylxanthine decreased to concentration $0.15 \mathrm{~g} / \mathrm{L}$ and the amount of 7 -methylxanthine increased to concentration $0.78 \mathrm{~g} / \mathrm{L}$, with formation of xanthine at concentration $0.32 \mathrm{~g} / \mathrm{L}$. By $84 \mathrm{~h}$ all metabolites were completely utilized (Dash and Gummadi, 2010).

Wastes containing high concentrations of water-soluble nicotine have been classified as toxic and hazardous for human health and the environment. Biodegradation is a viable method for nicotine removal. Microorganisms able to degrade nicotine include Pseudomonas species. For example, Pseudomonas sp. Nic22 is the isolate with higher capacity for degradation than other studied 17 strains. Compared to the pure nicotine, this strain could decompose the substance in tobacco extract with less intermediates detected (Chen et al., 2008) Pseudomonas sp. ZUTSKD was able to grow and degrade nicotine at substrate concentrations 2-5.8 g/L. At $30^{\circ} \mathrm{C}$ and $\mathrm{pH} 7.0$, with additional $15 \mathrm{~g} / \mathrm{L}$ $\mathrm{Na}_{2} \mathrm{HPO}_{4} \times 6 \mathrm{H}_{2} \mathrm{O}$ and $6 \mathrm{~g} / \mathrm{L} \mathrm{KH}_{2} \mathrm{PO}_{4}$ in $5 \%$ TWE (tobacco waste extract), Pseudomonas sp. ZUTSKD could utilize $97 \%$ of nicotine $(1.6 \mathrm{~g} / \mathrm{L})$ in $12 \mathrm{~h}$. The strain degraded nicotine completely when the reducing sugar concentration in TWE was lower than $8 \mathrm{~g} / \mathrm{L}$. Yeast extract and phosphate additions improved nicotine degradation in 5\% TWE (Zhong et al., 2010). However, biodegradation of the tobacco nicotine is carried out by diverse biochemical pathways. Some metabolic intermediates may be harmful for health or environment, so it is essential to further study the conversion products before transferring the biotechnology to industry.

Toner used in copiers and printers releases significant quantities of waste. Toner powders consist of very small thermoplastic particles, usually styrene-acrylate copolymer. Black toners contain carbon black or iron oxides as pigments, color toners additionally include various organic pigments. Such additives as wax, silica and minor mineral amounts also can be components of the powder. It seems natural therefore, that these wastes are considered to be toxic to human health and the environment. However, certain bacteria, including Pseudomonas species can solve this problem. It was stated that some strains inoculated in minimal salt media were able to grow successfully in the presence of toner powder. Among various tested combinations, mix of $2 \mathrm{~g}$ powder and $10 \mathrm{~g}$ soil provided for the best bacterial growth (Sepperumal et al., 2014).

1-Propanethiol (PT) is an important mercaptan primarily resulting from anaerobic decomposition of proteins and it appears to be severely toxic to humans. $P$. putida S-1 isolated from activated sludge is able to degrade this compound. Addition of PT in the preincubation medium could enhance PT degradation. Cells pre-grown in media containing mercaptan degraded $28 \mathrm{mg} / \mathrm{L}$ of PT within $10 \mathrm{~h} \mathrm{in}$ contrast to cells pre-grown in other media (the least time $15 \mathrm{~h}$ ). P. putida S-1 cultivated in stirred tank reactor removed $86 \%$ of PT with inlet concentration of approximately $100 \mathrm{mg} / \mathrm{m}^{3}$ after $12 \mathrm{~h}$. Disposal efficiency increased to almost $100 \%$ under the same conditions by $24 \mathrm{~h}$. Degradation exceeded $98 \%$ at concentration $200 \mathrm{mg} / \mathrm{m}^{3}$ and decreased at concentration $400 \mathrm{mg} / \mathrm{m}^{3}$, recovering with time. Additionally, gaseous isopropanol at $200 \mathrm{mg} / \mathrm{m}^{3}$ level could be effectively removed in the reactor when mixed with the stream of PT, reaching elimination degree of $88 \%$. Dipropyl disulfide, 3-hexanone, 2-hexanone, 3hexanol, 2-hexanol, and propanethiol S-oxide were identified as the major intermediates and $\mathrm{CO}_{2}, \mathrm{SO}_{4}{ }^{2-}$, and biomass were the final products of PT degradation (Chen et al., 2016).

Carbazole is carcinogenic and mutagenic heterocyclic compound found in the waste of various pharmaceutical, petrochemical and dye industries. Several bacteria including Pseudomonas have been reported to utilize carbazole. Pseudomonas sp. GBS.5 cells immobilized in polyvinyl alcohol-alginate attained the maximum carbazole degradation rate $(52.62 \mathrm{ppm} / \mathrm{h})$ in contrast to cells immobilized in calcium alginate beads ( $39.06 \mathrm{ppm} / \mathrm{h}$ ) (Bhatnagar et al., 2016). Another experiment proved that phenol can be used as the sole carbon and energy source for Pseudomonas spp. ETL 2412. Phenol in water and effluents is the major organic chemical associated with various applications. However, this compound is hazardous to human health. The bacterium decomposed phenol to $76.43 \pm 1.23 \mathrm{mg} / \mathrm{L}$ concentration from an initial value $200 \mathrm{mg} / \mathrm{L}$. Phenol removal efficiency changed with cultural conditions. The optimal parameters for phenol decay were found at $\mathrm{pH} 7.5(82.63 \%)$, temperature $30^{\circ} \mathrm{C}(78.69 \%)$ and $0.25 \%$ supplemented glucose level (98.28\%) (Shah et al., 2014).

Mineral oil released into the environment is able to affect health of many living organisms. Moreover, oil contamination causes detrimental effect on soil properties such as fertility, permeability, water-holding and binding capacity. Biodegradation is a promising method to eliminate oil spills by microorganisms capable to utilize toxic contaminants as a source of carbon and energy. One experiment revealed that isolates of $P$. fluorescens degraded $68.5 \%$ of waste lubricating oil in a week. However, Acinetobacter sp. was more effective than Pseudomonas (71.9\% of the oil after 7 days) (Umar et al., 2013). The other experiment showed ability of Pseudomonas sp. to degrade motor oil. $70.61 \%$ of oil pollution was gone following 6 days of bacterial inoculation. However, oil is composed only of hydrocarbons, while the bacteria require extra nutrients for fast degradation rate. Addition of glycerol increases decomposition extent to $85.61 \%$. Inorganic salts promote bioconversion of $93.18 \%$ oil. In case of the surfactant $81.82 \%$ oil cleavage was recorded on the final day of incubation. Combination of glycerol and inorganic salts resulted in degradation of $96.97 \%$ oil. It was found to be the most effective treatment intensifying oil break-down (Sathiya-Moorthi $\boldsymbol{e}$ al., 2008). $P$. aeruginosa $\mathrm{DQ} 8$ was able to grow with diesel oil and crude oil as the sole carbon and energy sources, digesting the wide range of their components. $83 \pm 1.0 \%$ of total petroleum hydrocarbons (TPHs) of diesel oil were degraded and most of the fractions, including $\mathrm{C} 12-\mathrm{C} 25 \mathrm{n}$-alkanes were consumed by the strain. $79.3 \pm 0.85 \%$ of crude oil TPHs were transformed, and more than $60 \%$ of those were decomposed in the first $5 \mathrm{~d}$. The strain efficiently utilized various oil fractions. The alkane fraction was distinguished by the fastest degradation rate. The others, such as the aromatic hydrocarbon, nonhydrocarbon and asphaltene fractions were split by $52.3 \pm 2.1 \%, 66.3 \pm 5.3 \%$ and $46.6 \pm 3.4 \%$, respectively (Zhang et al., 2011).

The other studies traced ability of some bacteria, including Pseudomonas to use chitin or keratin as carbon sources that enhance crude oil removal. Bacterial cultures were grown on media with oil, or oil supplemented with chicken-feathers or shrimp wastes. Keratinolytic bacteria were better enzyme producers than the chitinolytic ones. The presence of organic, mainly keratinous wastes promoted oil hydrocarbon disposal to $90 \%$, detoxifying thereby doses of the pollutant over $58.300 \mathrm{mg} / \mathrm{L}$ in a relatively short period. Oil degradation in the presence of chicken-feathers was 3.8 times more intense than with shrimp wastes, and almost twice as active in comparison with oil-only cultures (Cervantes-González et al., 2008).

Pseudomonas may cope with cyanide contamination. Significant sources of cyanide pollution are anthropogenic activities such as cyanidation process in the mining industry. It is a highly reactive chemical forming metal-complexes harmful to the environment. Cyanide is mostly removed from industrial effluents by alkaline chlorination, hydrogen peroxide or ozonation. However, these methods produce hazardous end-products. Some bacteria, including Pseudomonas are able to decompose cyanide and thiocyanate. They degraded 250 and $450 \mathrm{mg} / \mathrm{L} \mathrm{CN}^{-}$, achieving disposal efficiency of 80 and $32 \%$ within 150 $\mathrm{h}$, respectively. Additionally, the $\mathrm{SCN}^{-}$degradation degree was 78 and $98 \%$ for non- and cyanide-spiked cultures (Mekuto et al., 2016).

Dye contamination is a critical ecological problem. There are over 100000 commercially marketed dyes, with more than $7 \times 10^{7}$ tons produced annually worldwide (Rafi et al., 1990). Dyes are widely used in textile, food industries, cosmetics and printing. Huge amounts of dye-saturated textile fabrication effluents pose grave environmental challenges. $10-15 \%$ of pigments are wasted in the course of dyeing process (Zollinger, 1987). Dye contamination characterized by toxicity, carcinogenicity and mutagenicity raises dramatic public health concern. Additionally, dyes obstruct light penetration and oxygen transfer in water bodies and may persist in the environment for an extended period of time. Use of physical and chemical methods in contrast to biological treatment of dye-contaminated wastewater is expensive and sometimes produces hazardous by-substances multiplying pollution problems. On the other hand, some microorganisms are capable to cause decolorizing effect. The results showed that in fed-batch process, $P$. oleovorans transformed $50 \mathrm{mg}$ of dye in $192 \mathrm{~h}$. However, when decolorization was performed in the anoxic reactor, bacterial culture fully degraded $25 \mathrm{mg}$ of dye during 24 hours (Silveira et al., 2011). P. aeruginosa ETL-1 was shown to disrupt three triarylmethane dyes within $24 \mathrm{~h}$. Under shaking conditions, percentages of dye decolorization were $90 \%, 75 \%$, and $66 \%$ for basic violet 14 , basic violet 3 , and acid blue 90 , respectively, whereas poor decolorization $(<30 \%)$ was recorded for all three dyes under static conditions. Triticum aestivum and Lens esculenta were used in dye phytotoxicity studies. The length of shoots, roots, and seedlings was more significantly affected by the tested dyes rather than by their degradation metabolites, indicating less toxic nature of the latter (Shah et al., 2013a). Decolorization rates can be changed by varying cultural conditions. The optimum $\mathrm{pH}$ and temperature values for depigmentation usually are $7-9$ and about $37^{\circ} \mathrm{C}$, respectively. Elevated concentrations of dyes and oxygen, addition of heavy metals decelerate bleaching process. Such compounds as glucose, peptone, yeast extract, or starch promote decolorization to a certain extent. Yet increased concentrations of these compounds may cause the interfering action because the bacteria will utilize them instead of the dyes (Shah et al., 2013a,b,c). The purified laccase enzyme (EC 1.10.3.2) derived from $P$. fluorescens was shown to decompose congo red with maximum effect upon $96 \mathrm{~h}$ (38.09\%) (Vandana and Peter, 2014).

\section{USE OF WASTE SUBSTRATES IN PRODUCTION OF VARIOUS COMPOUNDS BY PSEUDOMONAS}

\section{Wastes in biosurfactant production}

Pseudomonas strains can be used in utilization of waste vegetable oils. The food industry and households produce and consume frying oils in large quantities. The experiments revealed bacterial ability to utilize these substrates. Most of the tested Pseudomonas cultures showed satisfactory growth on basal medium with $2 \%$ or $4 \%$ used olive or sunflower oil. Additionally, used olive oil induced biosurfactant production (Haba et al., 2000). Residues from corn, babassu, 
cottonseed, palm oil refinery and soybean soapstock waste as the best substrate generating $11.7 \mathrm{~g} / \mathrm{L}$ of rhamnolipids, can be used for biosurfactant production (Nitschke et al., 2005). Enhanced degradation of oil-rich soybean wastes (acid oil, deodorizer distillate, soapstock) and increased biosurfactant production in comparison with soybean oil was demonstrated by $P$. aeruginosa MR01. Among these wastes soapstock provided for maximum specific growth rate, higher extent of biodegradation and biosurfactant purity grade (Partovi et al., 2013). Similar experiments were carried out with orange peelings, carrot peel waste, lime peelings, coconut oil cake, and banana waste. The orange peel was found to be the best substrate for generation of $9.18 \mathrm{~g} / \mathrm{L}$ of rhamnolipid biosurfactant reducing surface tension down to $31.3 \mathrm{mN} / \mathrm{m}$ (George \& Jayachandran, 2009).It was established that biosurfactants can be produced by Pseudomonas utilizing distillery and whey wastes (Babu $\boldsymbol{e t}$ al., 1996), waste motor lubricant oil and peanut oil cake (Thavasi et al., 2011), waste frying rice bran oil (Venkatesh and Vedaraman, 2012), waste frying coconut oil (George \& Jayachandran, 2013), corn steep liquor and molasses (Gudiña et al., 2013), distillery waste with other industrial wastes viz. curd whey waste, fruit processing waste and sugar refining effluent (Dubey et al., 2012), waste rapeseed oil (Możejko and Ciesielski, 2014), saponified waste palm oil (Możejko and Ciesielski, 2013). Al these wastes show great potential as cheap and high-energy sources in production of valuable compounds by Pseudomonas genus.

Various non-traditional oils such as jatropha oil, karanja oil and neem oil may be applied as renewable and low cost substrates for rhamnolipid production. These oils cannot be used for edible purposes either due to a strong disagreeable odor or toxic components. Such exotic oils contain various minor constituents that may affect the metabolic activity of microbes and hence rhamnolipid synthesis. Neem oil contains a number of triterpenoids, mainly azadirachtin $(0.4-0.9 \%)$ which act as an insecticide and thioketone as aromatic. Karanja oil contains flavonoids such as karanjin $(2.2-4.5 \%)$ and pongamol $(0.4-0.9 \%)$ possessing insect-repelling properties. Jatropha oil contains curcin, lectins and most toxic phorbol esters $(0.6 \%)$ distinguished by carcinogenic activity. However, experiments revealed that jatropha and karanja oils can be used in biosurfactant production (Pratap $\boldsymbol{e}$ al., 2011). Phorbol esters are also components of seed cake generated as byproduct in the course of biodiesel process based on Jatropha seeds. Phorbo esters are known to display toxic properties, so that seed cake cannot be consumed as cattle feed, unlike other oilseeds. These compounds can cause environmental problems and aren't destroyed even by heating at $160^{\circ} \mathrm{C}$ for 30 min. Nevertheless, $P$. aeruginosa PseA completely degraded phorbol esters in nine days under optimal conditions (Joshi et al., 2011)

\section{Wastes in production of polyhydroxyalkanoates}

Such media as glycerol, cassava wastewater (CW), waste cooking oil and CW with waste frying oils can be used as cheap carbon substrates in production of both rhamnolipids and PHAs. The results show that composition of rhamnolipids and PHAs varies with both the carbon source and the applied strain. The best combination is use of strain $P$. aeruginosa L2-1 with mix of $\mathrm{CW}$ and waste frying oil as the carbon source (Costa et al., 2009). Sugar refinery waste (cane molasses) with urea served as the potent nitrogen source used in production of PHA, like poly-3-hydroxybutyrate (PHB). Under optimal conditions maximum biomass level and PHB production - $7.60 \mathrm{~g} / \mathrm{L}$ and $5.32 \mathrm{~g} / \mathrm{L}$, respectively, were achieved after $54 \mathrm{~h}$ of fermentation. Total sugar concentration decreased to 17.8 $\mathrm{g} / \mathrm{L}$ at the end of production phase in comparison with initial concentration of 40 g/L (Tripathi et al., 2012). The experiments showed that glycerol as the byproduct of biodiesel manufacturing from kitchen chimney dump lard proved the better source for PHA synthesis than commercial glycerol, sugarcane molasses and glucose. Such glycerol application contributes into cost reduction of biodiesel technology by engaging side product as the main ingredient of nutrient medium (Phukon et al., 2014). Pseudomonas sp. strain DR2 synthesized PHA from glucose, citrate, glycerol, palmitate, corn oil, and waste vegetable oil $37.34 \%$ and $23.52 \%$ PHA levels were attained using corn oil and waste vegetable oil, respectively. Composition of these compounds depended on different substrates. PHA from corn oil consists of three major 3-hydroxyalkanoates: octanoic (C8:0, 37.75\% of the total 3-hydroxyalkanoate content), decanoic (C10:0, 36.74\%), and dodecanoic $(\mathrm{C} 12: 0,11.36 \%)$. The proportion of 3 hydroxyalkanoates in the waste PHA derived from vegetable oil is hexanoic $(5.86 \%)$, octanoic $(45.67 \%)$, decanoic $(34.88 \%)$, tetradecanoic $(8.35 \%)$, and hexadecanoic (5.24\%). It appears that inexpensive vegetable oil and waste can serve as alternative substrates for PHA production (Song et al., 2008).

Some reports pointed out that PHAs may be obtained using plastics, which will resolve both problem of waste disposal and synthesis of the end product. Polystyrene can be converted into the desired compound in two steps. The first step involves the pyrolysis of polystyrene to styrene oil at the temperature $520^{\circ} \mathrm{C}$. The process results in the generation of oil composed of styrene $(82.8 \%)$ and low levels of $\alpha$-methylstyrene, toluene, styrene dimer, and traces of other aromatic compounds. The second step includes bacterial transformation of the styrene oil to PHA by $P$. putida CA-3. Cells grown in shake flask culture consume $1 \mathrm{~g}$ of styrene oil to yield $62.5 \mathrm{mg}$ of PHA and $250 \mathrm{mg}$ of bacterial biomass. A low level of PHA accumulation was observed in the first $10 \mathrm{~h}$ of growth, followed by a dramatic rise between 16 and $24 \mathrm{~h}$, and a steep fall thereafter. After $48 \mathrm{~h}$ of fermentation $1.6 \mathrm{~g}$ of PHA and $2.8 \mathrm{~g}$ of bacterial biomass was derived from $16 \mathrm{~g}$ styrene oil by $P$. putida CA-3 in a 7.5 liter stirred tank reactor (Ward et al. 2006). Change of nitrogen concentration exerts some effect on cell dry weight and PHA production. At supply rate $1 \mathrm{mg} \mathrm{N} / \mathrm{l} / \mathrm{h} 1.1$-fold rise of PHA ratio in dry biomass was recorded. The maximum amount of PHA (4.2 g) produced from styrene by $P$. putida CA-3 in the bioreactor occurred at nitrogen feed rate 1.5 $\mathrm{mg} / \mathrm{l} / \mathrm{h}$. The rates 1.75 and $2 \mathrm{mg} \mathrm{N} / \mathrm{l} / \mathrm{h}$ resulted in critical decrease of PHA intracellular level (Goff $\boldsymbol{e t}$ al., 2007). Polyethylene terephthalate also can serve as the substrate for PHA production. Conversion of polyethylene terephthalate similar to polystyrene proceeds in two stages: pyrolysis to styrene oil followed by Pseudomonas production of polymers. P. putida strains accumulated PHA with maximal productivity of approximately $8.4 \mathrm{mg} \mathrm{PHA} / \mathrm{l} / \mathrm{h}$ for $12 \mathrm{~h}$ before the synthesis rate fell sharply. $P$. frederiksbergensis accumulated PHA at the highest rate of $4.4 \mathrm{mg} \mathrm{PHA} / \mathrm{l} / \mathrm{h}$ but there was no slow down in the production rate over time (Kenny et al., 2008). P. aeruginosa PAO-1 synthesized biomass with almost $25 \%$ PHA content when supplied with the polyethylene pyrolysis wax in the presence of rhamnolipids. The change of nitrogen source from ammonium chloride to ammonium nitrate resulted in faster bacterial growth and the earlier onset of PHA accumulation (Guzik et al., 2014).

\section{Wastes in production of enzymes}

Up to $30-40 \%$ of the production costs of industrial enzymes are accounted for by the growth substrates. The use of cost-effective growth medium for the synthesis of proteases can significantly improve economics of the process. For example, $P$. aeruginosa MN7 was shown to grow on the shrimp waste powder as the sole source of carbon, nitrogen, and salts. The strain was found to produce protease (elastase) (EC 3.4.24.26), with maximal synthesis of the enzyme at substrate concentration $60 \mathrm{~g} / \mathrm{L}$ (Jellouli et al., 2008). Wheat bran can be used as the feedstock for production of alkaline protease by $P$. aeruginosa. The higher levels of protease activity could be achieved using the following cultural conditions: wheat bran concentration $(5 \%, \mathrm{w} / \mathrm{v}) ; \mathrm{pH}(9.0) ; \mathrm{NaCl}(12.5 \%)$; temperature $\left(45^{\circ} \mathrm{C}\right)$; inoculum size $(5 \mathrm{ml})$; incubation period $(48 \mathrm{~h})$ and agitation rate $(100$ $\mathrm{rpm}$ ). Under these conditions, $P$. aeruginosa produced alkaline protease (EC 3.4.24.40) showing activity 582.25 $\pm 9.2 \mathrm{U} / \mathrm{ml}$ (Meena et al., 2013). Anima fleshing, a solid waste generated by tanning industry, also can be used as the only source of nitrogen and carbon for synthesis of alkaline proteases. The enzyme produced by $P$. aeruginos $a$ reached maximal activity $(1160-1175 \mathrm{U} / \mathrm{mL})$ after 20 hours of incubation. That protease preferentially degraded non-fibrillar proteins like albumin and globulin. However, increasing amino acid content in the exocellular medium suppressed protease activity upon further fermentation (Kumar et al., 2008).

Microbial strains are essential in control of castor oil wastes. Two different $P$. aeruginosa strains are able to degrade castor oil with rates 5.7 and $3.8 \mathrm{~g} / \mathrm{L}$ a day. Additionally, these strains produce lipase (triacylglycerol acylhydrolase, EC 3.1.1.3) with maximum activity of 1121 and $470.82 \mathrm{U} / \mathrm{ml}$ at $37^{\circ} \mathrm{C}$ and activity of 358.72 and $147.18 \mathrm{U} / \mathrm{ml}$ at $75^{\circ} \mathrm{C}$. The activities were evaluated by the rate of $p$ nitrophenol production. Thus, $P$. aeruginosa strains can be used both in castor oil waste control and production of lipases (Amara and Salem, 2009; Sharon et al., 1998). Palm fatty acid distillates, crude soybean acid oil, and wastewater from soybean oil refining process added at $2 \%$ concentration to the basal medium were also tested as nutrient sources for lipase production. The results demonstrated that the maximum lipase synthesis was attained using wastewater from palm oil refining process $(70.29 \pm 0.09 \mathrm{U} / \mathrm{mg})$, followed by wastewater from soybean oil refining process $(62.59 \pm 0.38 \mathrm{U} / \mathrm{mg})$ and crude soybean acid oil $(62.48 \pm 0.43$ $\mathrm{U} / \mathrm{mg}$ ) (Supakdamrongkul et al., 2014).

Bacterial consortia, including some Pseudomonas strains ( $P$. fluorescence, $P$. putida) might be engaged in degradation of banana waste (leaves and pseudostem) by solid state fermentation for cellulase (EC 3.2.1.4) production. The consortia exhibited high levels of enzyme production and pattern of biosynthesis with maximum specific activities lying between 15 and 25 days (Dabhi et al., 2014)

\section{Wastes in production of pigments}

Another application for wastes is production of pigments, like melanin that mostly acts as antioxidant. Melanins find use in agriculture, medicine, cosmetic and pharmaceutical industries. It was found that vegetable waste from cabbage leftovers mixed with marine broth in 70:30 ratio is suitable for production of melanin $(2.79 \pm 0.2 \mathrm{mg} / \mathrm{mL})$ but the yields were lower compared with pure marine broth $(5.35 \pm 0.4 \mathrm{mg} / \mathrm{mL})$. Pigments from the different nutrient sources have shown different elemental composition. However, functional groups appeared to be the same (Tarangini and Mishra, 2013).

In order to find cheap medium for pigment production by $P$. fluorescens seven different combinations of agricultural wastes were tested. Combination IV (rice straw + rice husk + wheat husk + cow dung + coconut water) provided for both increased bacterial growth and high rate of green pigment (pyocyanin) production. Pyocyanin finds application in organic light emitting devices, biosensors as a redox compound, microbial fuel cells (MFC) as electron shuttle medicine as antitumor agent (El-Fouly et al., 2015). Combination VI (rice straw 
+ tapioca waste + cow dung + maida) was also found to be appropriate for growth but the production of pigments was relatively inferior to combination IV. The other variants turned out to be not adequate (Poorni et al., 2011).

\section{Other waste applications}

Tobacco wastes have potential application in the biosynthesis of valuable chemicals, especially pyridines, like SP. SP ( $\gamma$-oxo-3-pyridinebutanoic acid) is a simple molecular pyridine compound that can be transformed into hypotensive agents of mammals ( $\omega$-heteroaroyl-(propionyl)-1-prolines). P. putida $\mathrm{S} 16 \mathrm{dspm}$ is able to utilize nicotine and form the target metabolites. Under optimal conditions of fed-batch fermentation the engineered strain produced SP at concentrations 9.8 $\mathrm{g} / \mathrm{L}$ and $8.9 \mathrm{~g} / \mathrm{L}$ and conversion yields of $83.8 \%$ and $89.9 \%$ during $45 \mathrm{~h}$ from aqueous nicotine solution and crude suspension of the tobacco waste, respectively (Wang $\boldsymbol{e t}$ al., 2015). Another compound that can be produced from tobacco wastes is HSP. This metabolite is a potential building block in the synthesis of drugs, insecticides and other compounds possessing biological activities, such as the analgesic molecule epibatidine. Under optimal conditions, recombinant strain $P$. putida P-HSP generated HSP at concentrations $6.8 \mathrm{~g} / \mathrm{L}$ and $16.3 \mathrm{~g} / \mathrm{L}$ with productivity $0.25 \mathrm{~g} / \mathrm{L} / \mathrm{h}$ and $0.71 \mathrm{~g} / \mathrm{L} / \mathrm{h}$ and the yields $36 \%$ and $75 \%$ from tobacco waste and nicotine, respectively. The HSP concentration derived from crude tobacco waste extract was lower than from pure nicotine, probably, because the former carries complex components inhibiting enzyme activity. Nevertheless, in long-term perspective tobacco wastes may be regarded as substrates for production of valuable compounds (Yu et al., 2014).

Shrimp shell waste may serve as a source of chitin in production of chitosan used as fruit juice clarifier. The strain $P$. aeruginosa A2 was applied for chitin extraction. Demineralization advanced rapidly during the first three days of incubation period. At the same time, a swift $\mathrm{pH}$ drop took place. From the fourth day, these two parameters remained constant. Demineralization maximum (92\%) was achieved when $\mathrm{pH}$ of the culture equaled 4.4. However, protease activity reached its highest level $(1230 \mathrm{U} / \mathrm{mL})$ after 1 day of incubation, and $90 \%$ protein removal was recorded. Chitosan converted from chitin was found to be effective in the clarification of different fruit juices at low concentration $(0.025 \%$ for orange and apple juices and $0.1 \%$ for lemon juice), and it doesn't affect biochemical parameters of the juices. Presumably, it may serve as an ideal flocculation clarifier for fruit juices. Additionally, the antioxidant activity of shrimp waste hydrolysates produced during fermentation was tested. The result indicated that hydrolysates exhibited important radical-scavenging activities. The antioxidant activity increased and reached peak value after 3 days (90\%) (Ghorbell-Bellaaj et al., 2012). Similar experiment with crab shell waste samples allowed to study the effect of temperature, concentrations of shell waste and glucose, shell size on demineralization (DM) and deproteinization (DP) in the process of chitin extraction by $P$. aeruginosa F722. The optimal temperature for $\mathrm{DM}$ was found to be $30^{\circ} \mathrm{C}$. The efficiency of $\mathrm{DM}$ was $92 \%$, while the efficiency of DP was 63\%. DM and DP efficiencies decreased with the increase of the solid to liquid ratio. The best results were registered for $5 \%$ CS waste. $90.5 \%$ DM was achieved by 7 days of incubation with $10 \%$ glucose and $10 \%$ inoculum of $P$. aeruginosa. The DM rate was gradually increased for both large (particle size 20-35 $\mathrm{mm}$ ) and small $(3-10 \mathrm{~mm}$ ) shell samples during the cultivation. At day 7, the DM rates were $91.5 \%$ and $84.0 \%$ for the large and small size samples, respectively. The DP rates were $62 \%$ for the large size samples and $58.5 \%$ for the small ones (Oh et al., 2007).

About $30 \%$ of annual world cheese whey volume remains underutilized, ending up as waste or animal feed. The studied $P$. taetrolens strain is able to derive lactobionic acid from whey. Lactobionic acid displays antioxidant, biodegradable, biocompatible and chelating properties, and therefore it may fit into various applications. Membrane-bound system catalyzed lactose oxidation to lactone intermediate (lactobiono- $\delta$-lactone), with carbonyl group subsequently hydrolyzed by lactonase into lactobionic acid. The strain produced $42.4 \mathrm{~g} / \mathrm{L}$ lactobionic acid after $32 \mathrm{~h}$ fermentation started with a $30 \%$ inoculum volume, evidencing the role of cheese whey as an alternative substrate for production of this compound (Alonso et al., 2011).

Pseudomonas bacteria may be applied in biodegradation and conversion of excess waste glycerol. Glycerol is a colorless compound containing three hydroxyl groups in its structure. It is the by-product of fat processing, ethanolic fermentation of glucose and biodiesel industry released in growing amounts. The waste glycerol can be utilized as a carbon source for microbial growth and converted into various products, like 1,2-propanediol, 1,3-propanediol, succinic acid, ethanol, xylitol, propionate. Chemical synthesis of 1,3-propanediol demands high energy input and expensive catalysts while microbial metabolic route requires ambient temperature and atmospheric pressure (Deckwer, 1995; Hao et al., 2008). It is possible to transform glycerol into 1,3-propanediol using Pseudomonas strains, with the best results achieved in $72 \mathrm{~h}$ process at $50 \mathrm{~g} / \mathrm{L}$ glycerol concentration. In turn, 1,3-propanediol can be used in industrial production of unsaturated polyester resins showing fire and electrical resistance (Karve et al., 2014)

Wastes may be applied in fabrication of biofuel. Biofuel is usually produced by microbial fermentation of the sugars. World pulp and paper industry puts out about 300-350 million tons of paper and board of various types, so that paper wastes make a splendid source of biofuel, if two major plant components, starch and cellulose, are converted to sugars readily utilized by microorganisms. The studies indicated that the waste paper substrate (basically consisting of starch after chemical hydrolysis) was converted into simple fermentable sugar by $P$. aeruginosa. The product yield of the microbial hydrolysis of waste paper substrate was $45 \%$. It was enough for further production of ethanol by Saccharomyces cerevisiae (Prema et al., 2015).

Waste can be used as substrate for MFC. MFC converts energy available in a biological substrate directly into electricity. Cells function on different carbohydrates, including complex substrates in wastewaters and alleviate thereby environmental contamination problem. However, the tests showed lower coulombic efficiencies (the ratio of the output of charge to the input of charge) of complex wastewater substrates with the highest value of $36 \%$ as compared to easily degradable synthetic wastewaters with the peak level of $98 \%$ (Fornero et al., 2010). Nevertheless, some studies in this direction were carried out (Majumder et al., 2014).

\section{CONCLUSION}

Ability of Pseudomonas to produce and utilize a wide range of compounds makes this genus extremely attractive in various applications, including waste disposal. Investigations revealed Pseudomonas potential in degradation of agricultural, industrial and household wastes. It's especially important with regard to compounds hazardous for the environment and humans. Annually new studies concerning waste utilization emerge and the data show high efficiency of this bacterial genus in resolving contamination problems.

Moreover, metabolic versatility of Pseudomonas allows to gain valuable biological products, primarily biosurfactants and PHAs suitable for various industrial processes and often distinguished by superior properties than chemical analogs in terms of lower toxicity and biodegradability. As a result it's possible to manufacture a broad spectrum of bioactive agents using waste materials as the sole source of carbon and nitrogen.

\section{REFERENCES}

Alonso, S., Rendueles, M., \& Díaz, M. (2011). Efficient lactobionic acid production from whey by Pseudomonas taetrolens under $\mathrm{pH}$-shift conditions Bioresource technology, 102(20), 9730-9736 http://dx.doi.org/10.1016/j.biortech.2011.07.089

Amara, A. A., \& Salem, S. R. (2009). Degradation of castor oil and lipase production by Pseudomonas aeruginosa. American-Eurasian Journal of Agricultural \& Environmental Sciences, 5(4), 556-563.

Anderson, M. S., Hall, R. A., \& Griffin, M. (1980). Microbial Metabolism of Alicyclic Hydrocarbons: Cyclohexane Catabolism by a Pure Strain of Pseudomonas sp. Microbiology, 120(1), 89-94.

Babu, P. S., Vaidya, A. N., Bal, A. S., Kapur, R., Juwarkar, A., \& Khanna, P. (1996). Kinetics of biosurfactant production by Pseudomonas aeruginosa strain BS2 from industrial wastes. Biotechnology letters, 18(3), 263-268. http://dx.doi.org/10.1007/BF00142942

Beier, S., \& Bertilsson, S. (2014). Bacterial chitin degradation-mechanisms and ecophysiological strategies. The Microbial Regulation of Global Biogeochemical Cycles, 9. http://dx.doi.org/10.3389/fmicb.2013.00149

Bharathiraja, B., Jayamuthunagai, J., Jayakumar, M., Kirubakaran, M. A., Vivek, P., Chandran, M., \& Kumar, R. P. (2013). Biodegradation of Poly (vinyl alcohol) using Pseudomonas alcaligenes. Asian Journal of Chemistry, 25(15), 8663-8667. http://dx.doi.org/10.14233/ajchem.2013.14937

Bhatnagar, Y., Singh, G. B., Mathur, A., Srivastava, S., Gupta, S., \& Gupta, N. (2016). Biodegradation of carbazole by Pseudomonas sp. GBS. 5 immobilized in polyvinyl alcohol beads. Journal of Biochemical Technology, 6(3), 1003-1007.

Brandsch, R. (2006). Microbiology and biochemistry of nicotine degradation. Applied Microbiology and Biotechnology, 69(5), 493-498. http://dx.doi.org/10.1007/s00253-005-0226-0

Cerventes-González, E., Rojas-Avelizapa, N. G., Cruz-Camarillo, R., GarcíaMena, J., \& Rojas-Avelizapa, L. I. (2008) Oil-removal enhancement in media with keratinous or chitinous wastes by hydrocarbon-degrading bacteria isolated from oil-polluted soils. Environmental technology, 29(2), 171-182. http://dx.doi.org/10.1080/09593330802028659

Chamy, R., \& Rosenkranz, F. (2013). Biodegradation: life of science. InTech http://dx.doi.org/10.5772/52777

Chaturvedi, V., \& Verma, P. (2014). Metabolism of Chicken Feathers and Concomitant Electricity Generation by Pseudomonas aeruginosa by Employing Microbial Fuel Cell (MFC). Journal of Waste Management, 2014 http://dx.doi.org/10.1155/2014/928618

Chen, C., Li, X., Yang, J., Gong, X., Li, B., \& Zhang, K. Q. (2008). Isolation of nicotine-degrading bacterium Pseudomonas sp. Nic22, and its potential application in tobacco processing. International Biodeterioration \& Biodegradation, 62(3), 226-231. http://dx.doi.org/10.1016/j.ibiod.2008.01.012

Chen, D. Z., Sun, Y. M., Han, L. M., Chen, J., Ye, J. X., \& Chen, J. M. (2016). A newly isolated Pseudomonas putida S-1 strain for batch-mode-propanethiol degradation and continuous treatment of propanethiol-containing waste gas 
Journal of hazardous materials

302 ,

$232-240$ http://dx.doi.org/10.1016/j.jhazmat.2015.09.063

Chen, J., Zhang, Y., Du, G. C., Hua, Z. Z., \& Zhu, Y. (2007). Biodegradation of polyvinyl alcohol by a mixed microbial culture. Enzyme and Microbia Technology, 40(7)

http://dx.doi.org/10.1016/j.enzmictec.2006.09.010

1686-1691.

Chiellini, E., Corti, A., Del Sarto, G., \& D'Antone, S. (2006). Oxo-biodegradable polymers-Effect of hydrolysis degree on biodegradation behaviour of poly (viny alcohol). Polymer Degradation and stability, 91(12), 3397-3406. http://dx.doi.org/10.1016/j.polymdegradstab.2006.05.021

Costa, S. G., Lépine, F., Milot, S., Déziel, E., Nitschke, M., \& Contiero, J. (2009). Cassava wastewater as a substrate for the simultaneous production of rhamnolipids and polyhydroxyalkanoates by Pseudomonas aeruginosa. Journal of industrial microbiology \& biotechnology, 36(8), 1063-1072. http://dx.doi.org/10.1007/s10295-009-0590-3

Dabhi, B. K., Vyas, R. V., \& Shelat, H. N. (2014). Use of banana waste for the production of cellulolytic enzymes under solid substrate fermentation using bacterial consortium. International Journal of Current Microbiology and Applied Sciences, 3(1), 337-346.

Dash, S. S., \& Gummadi, S. N. (2010). Biodegradation of caffeine by Pseudomonas sp. NCIM 5235. Research Journal of Microbiology, 5(8), 745-753. http://dx.doi.org/10.3923/jm.2006.115.123

Deckwer, W. D. (1995). Microbial conversion of glycerol to 1, 3-propanediol. FEMS Microbiology Reviews, 16(2-3), 143-149. http://dx.doi.org/10.1016/0168 6445(94)00050-9

Dubey, K. V., Charde, P. N., Meshram, S. U., Yadav S. K., Singh, S., \& Juwarkar, A. A. (2012) Potential of New Microbial Isolates for Biosurfactant Production using Combinations of Distillery Waste with other Industrial Wastes. Journal of Petroleum \& Environmental Biotechnology, S1:002 http://dx.doi.org/10.4172/2157-7463.S1-002

El-Fouly, M. Z., Sharaf, A. M., Shahin, A. A. M., El-Bialy, H. A., \& Omara, A. M. A. (2015). Biosynthesis of pyocyanin pigment by Pseudomonas aeruginosa. Journal of Radiation Research and Applied Sciences, 8(1), 36-48. http://dx.doi.org/10.1016/j.jrras.2014.10.007

Fall, R. R., Brown, J. L., \& Schaeffer, T. L. (1979). Enzyme recruitment allows the biodegradation of recalcitrant branched hydrocarbons by Pseudomonas citronellolis. Applied and Environmental Microbiology, 38(4), 715-722.

Fornero, J. J., Rosenbaum, M., \& Angenent, L. T. (2010). Electric power generation from municipal, food, and animal wastewaters using microbial fuel cells. Elecroanalysis, 22(7-8), 832-843. http://dx.doi.org/10.1002/elan.200980011 George, S., \& Jayachandran, K. (2009). Analysis of rhamnolipid biosurfactants produced through submerged fermentation using orange fruit peelings as sole carbon source. Applied biochemistry and biotechnology, 158(3), 694-705. http://dx.doi.org/10.1007/s12010-008-8337-6

George, S., \& Jayachandran, K. (2013). Production and characterization of rhamnolipid biosurfactant from waste frying coconut oil using a novel Pseudomonas aeruginosa D. Journal of applied microbiology, 114(2), 373-383. http://dx.doi.org/10.1111/jam.12069

Ghorbel-Bellaaj, O., Jridi, M., Khaled, H. B., Jellouli, K., \& Nasri, M. (2012), Bioconversion of shrimp shell waste for the production of antioxidant and chitosan used as fruit juice clarifier. International Journal of Food Science \& Technology, 47(9), 1835-1841. http://dx.doi.org/10.1111/j.13652621.2012.03039.x

Goff, M., Ward, P. G., \& O'Connor, K. E. (2007). Improvement of the conversion of polystyrene to polyhydroxyalkanoate through the manipulation of the microbial aspect of the process: A nitrogen feeding strategy for bacterial cells in a stirred tank reactor. Journal of biotechnology, 132(3), 283-286. http://dx.doi.org/10.1016/j.jbiotec.2007.03.016

Gudiña, E. J., Rodrigues, A. I., Teixeira, J. A., \& Rodrigues, L. R. (2013) Improved biosurfactant production by a Pseudomonas aeruginosa strain using agro-industrial wastes.

Guzik, M. W., Kenny, S. T., Duane, G. F., Casey, E., Woods, T., Babu, R. P., ... \& O'Connor, K. E. (2014). Conversion of post consumer polyethylene to the biodegradable polymer polyhydroxyalkanoate. Applied microbiology and biotechnology, 98(9), 4223-4232. http://dx.doi.org/10.1007/s00253-013-5489-2

Haba, E., Espuny, M. J., Busquets, M., \& Manresa, A. (2000). Screening and production of rhamnolipids by Pseudomonas aeruginosa 47T2 NCIB 40044 from waste frying oils. Journal of Applied Microbiology, 88(3), 379-387. http://dx.doi.org/10.1046/j.1365-2672.2000.00961.x.

Hao, J., Lin, R., Zheng, Z., Liu, H., \& Liu, D. (2008). Isolation and characterization of microorganisms able to produce 1, 3-propanediol under aerobic conditions. World Journal of Microbiology and Biotechnology, 24(9), 1731-1740. http://dx.doi.org/10.1007/s11274-008-9665-y

Imelik, B. (1948). Oxydation du cyclohexane par Pseudomonas aeruginosa Comptes Rendus de l'Académie des Sciences, 226, 2082-2083.

Jellouli, K., Bayoudh, A., Manni, L., Agrebi, R., \& Nasri, M. (2008). Purification, biochemical and molecular characterization of a metalloprotease from Pseudomonas aeruginosa MN7 grown on shrimp wastes. Applied $\begin{array}{llll}\text { microbiology and biotechnology, 79(6), 989-999. } & \end{array}$ http://dx.doi.org/10.1007/s00253-008-1517-z
Joshi, C., Mathur, P., \& Khare, S. K. (2011). Degradation of phorbol esters by Pseudomonas aeruginosa PseA during solid-state fermentation of deoiled Jatropha curcas seed cake. Bioresource technology, 102(7), 4815-4819. http://dx.doi.org/10.1016/j.biortech.2011.01.039

Karve, M., Patel, J. J., Sinha, V. K., \& Patel, N. K. (2014). Bioconverison of waste glycerol to 1, 3-propanediol and its application. Acc Biotechnology Research, 1(1), 29-33.

Kenny, S. T., Runic, J. N., Kaminsky, W., Woods, T., Babu, R. P., Keely, C. M., ... \& O'Connor, K. E. (2008). Up-cycling of PET (polyethylene terephthalate) to the biodegradable plastic PHA (polyhydroxyalkanoate). Environmental science \& technology, 42(20), 7696-7701. http://dx.doi.org/10.1021/es801010e

Kumar, A. G., Swarnalatha, S., Sairam, B., \& Sekaran, G. (2008). Production of alkaline protease by Pseudomonas aeruginosa using proteinaceous solid waste generated from leather manufacturing industries. Bioresource Technology, 99(6), 1939-1944. http://dx.doi.org/10.1016/j.biortech.2007.03.025

Kyaw, B. M., Champakalakshmi, R., Sakharkar, M. K., Lim, C. S., \& Sakharkar, K. R. (2012). Biodegradation of Low Density Polythene (LDPE) by Pseudomonas Species. Indian Journal of Microbiology, 52(3), 411-419. http://doi.org/10.1007/s12088-012-0250-6

Liu, Y., Wang, L., Huang, K., Wang, W., Nie, X., Jiang, Y., ... Tang, H. (2014). Physiological and Biochemical Characterization of a Novel Nicotine-Degrading Bacterium Pseudomonas geniculata N1. PLoS ONE, 9(1), e84399. http://doi.org/10.1371/journal.pone.0084399

Lucas, N., Bienaime, C., Belloy, C., Queneudec, M., Silvestre, F., \& NavaSaucedo, J. E. (2008). Polymer biodegradation: Mechanisms and estimation techniques. Chemosphere, 73(4),

http://doi.org/10.1016/i.chemosphere.2008.06.064

Majumder, D., Maity, J. P., Tseng, M. J., Nimje, V. R., Chen, H. R., Chen, C. C. ... \& Chen, C. Y. (2014). Electricity generation and wastewater treatment of oil refinery in microbial fuel cells using Pseudomonas putida. International journal of molecular sciences, $15(9), \quad 16772-16786$. http://dx.doi.org/10.3390/ijms150916772

Meena, P., Tripathi, A. D., Srivastava, S. K., \& Jha, A. (2013). Utilization of agro-industrial waste (wheat bran) for alkaline protease production by Pseudomonas aeruginosa in SSF using Taguchi (DOE) methodology. Biocatalysis and Agricultural Biotechnology, 2(3), 210-216. http://dx.doi.org/10.1016/j.bcab.2013.05.003

Mekuto, L., Ntwampe, S. K. O., Kena, M., Golela, M. T., \& Amodu, O. S. (2016). Free cyanide and thiocyanate biodegradation by Pseudomonas aeruginosa STK 03 capable of heterotrophic nitrification under alkaline conditions. 3 Biotech, 6(1), 1-7. http://dx.doi.org/10.1007/s13205-015-0317-2

Możejko, J., \& Ciesielski, S. (2013). Saponified waste palm oil as an attractive renewable resource for mcl-polyhydroxyalkanoate synthesis. Journal of $\begin{array}{lll}\text { bioscience and bioengineering, 116(4), 485-492. } & \end{array}$ http://dx.doi.org/10.1016/j.jbiosc.2013.04.014

Możejko, J., \& Ciesielski, S. (2014). Pulsed feeding strategy is more favorable to medium-chain-length polyhydroxyalkanoates production from waste rapeseed $\begin{array}{llll}\text { oil. Biotechnology } & \text { 1243-1246. }\end{array}$ http://dx.doi.org/10.1002/btpr.1914

National Research Council. (1985). Oil in the Sea: Inputs, Fates, and Effects Washington, DC: The National Academies Press. http://dx.doi.org/10.17226/314 Nitschke, M., Costa, S. G., Haddad, R., Gonçalves, G., Lireny, A., Eberlin, M. N., \& Contiero, J. (2005). Oil wastes as unconventional substrates for rhamnolipid biosurfactant production by Pseudomonas aeruginosa LBI Biotechnology progress, 21(5), 1562-1566. http://dx.doi.org/10.1021/bp050198x Oh, K. T., Kim, Y. J., Jung, W. J., \& Park, R. D. (2007). Demineralization of crab shell waste by Pseudomonas aeruginosa F722. Process Biochemistry, 42(7), 1069-1074. http://dx.doi.org/10.1016/j.procbio.2007.04.007

Partovi, M., Lotfabad, T. B., Roostaazad, R., Bahmaei, M., \& Tayyebi, S. (2013) Management of soybean oil refinery wastes through recycling them for producing biosurfactant using Pseudomonas aeruginosa MR01. World Journal of $\begin{array}{llll}\text { Microbiology and Biotechnology, 29(6), 1039-1047. } & \end{array}$ http://dx.doi.org/10.1007/s11274-013-1267-7

Phukon, P., Phukan, M. M., Phukan, S., \& Konwar, B. K. (2014) Polyhydroxyalkanoate production by indigenously isolated Pseudomonas aeruginosa using glycerol by-product of KCDL biodiesel as an inexpensive carbon source. Annals of Microbiology, 64(4), 1567-1574. http://dx.doi.org/10.1007/s13213-014-0800-8.

Poorni, K. E., Manikandan, A., Geethanjali, S., \& Percy, P. K. (2011). Production of Pseudomonas fluorescens from agricultural wastes and its application in the preservation of selected vegetables. Advances in Applied Science Research, 2(2), 156-160.

Pratap, A., Wadekar, S., Kale, S., Lali, A., \& Bhowmick, D. N. (2011). Nontraditional oils as newer feedstock for rhamnolipids production by Pseudomona aeruginosa (ATCC 10145). Journal of the American Oil Chemists' Society, 88(12), 1935-1943. http://dx.doi.org/10.1007/s11746-011-1875-Z

Prema, D., Prabha, M. L., \& Gnanavel, G. (2015). Production of Biofuel using Waste Papers from Pseudomonas aeruginosa. International Journal of ChemTech Research, 8(4), 1803-1809. 
Qiu, J., Ma, Y., Wen, Y., Chen, L., Wu, L., \& Liu, W. (2012). Functional identification of two novel genes from Pseudomonas sp. strain HZN6 involved in the catabolism of nicotine. Applied and environmental microbiology, 78(7), 2154-2160. http://dx.doi.org/10.1128/AEM.07025-11

Rafi, F., Fraeankalin, W., \& Cerniglia, C. E. (1990). Optimization of cultural condition for decolorization of textile effluent. Applied and Environmental Microbiology, 56, 2146.

Raman, G., Mohan, K., Manohar, V., \& Sakthivel, N. (2014). Biodegradation of nicotine by a novel nicotine-degrading bacterium, Pseudomonas plecoglossicida TND35 and its new biotransformation intermediates. Biodegradation, 25(1), 95107. http://dx.doi.org/10.1007/s10532-013-9643-4

Satpute, S. K., Bhuyan, S. S., Pardesi, K. R., Mujumdar, S. S., Dhakephalkar, P. K., Shete, A. M., \& Chopade, B. A. (2010). Molecular genetics of biosurfactant synthesis in microorganisms. In Biosurfactants (pp. 14-41). Springer New York. http://dx.doi.org/10.1007/978-1-4419-5979-9_2

Ramos, J. L. (2004). Pseudomonas: Volume 3 Biosynthesis of Macromolecules and Molecular Metabolism. Springer US. http://dx.doi.org/10.1007/978-1-44199088-4

Rehm, B. H. (Ed.). (2008). Pseudomonas: model organism, pathogen, cell factory. John Wiley \& Sons. http://dx.doi.org/10.1002/9783527622009

Robbins, W. K., \& Hsu, C. S. (2000). Petroleum, Composition. Kirk-Othmer Encyclopedia of Chemical Technology. http://dx.doi.org/10.1002/0471238961.0315131618150202.a01

Sanuth, H. A., Ogunjobi A. A., \& Fagade O. E. (2015) Hydrolytic degradation of nylon-6 by Pseudomonas aeruginosa HE858284 isolated from solid waste dumpsites in Lagos State, Nigeria. Journal of Natural Sciences Research, 5(2), 130-138.

Sathiya-Moorthi, P., Deecaraman, M., \& Kalaichelvan, P. T. (2008) Bioremediation of automobile oil effluent by Pseudomonas sp. Advanced biotech, 31, 34-37.

Sepperumal, U., Selvanayagam, S., \& Markandan, M. (2014). Utilization of toner waste black powder for bacterial growth. Journal of Microbiology and Biotechnology Research, 4(1), 28-30.

Shah, M. P., Patel, K. A., Nair, S. S., \& Darji, A. M. (2013a). Environmental bioremediation of dyes by Pseudomonas aeruginosa ETL-1 isolated from final effluent treatment plant of Ankleshwar. American Journal of Microbiological Research, 1(4), 74-83. http://dx.doi.org/10.12691/ajmr-1-4-3

Shah, M. P., Patel, K. A., Nair, S. S., \& Darji, A. M. (2013b). Microbial decolourization of methyl orange dye by Pseudomonas spp. OA Biotechnology, 2(1), 10. http://dx.doi.org/10.13172/2052-0069-2-1-497

Shah, M. P., Patel, K. A., \& Darji, A. M. (2013c). Microbial Decolorization of Reactive Black by Pseudomonas stutzeri ETL-79. International Journal of Environmental Bioremediation \& Biodegradation, 1(2), 37-42. http://dx.doi.org/10.4172/2155-6199.1000197

Shah, M. P. (2014). Microbiological Removal of Phenol by an Application of Pseudomonas spp. ETL-: An Innovative Biotechnological Approach Providing Answers to the Problems of FETP. Journal of Applied \& Environmental Microbiology, 2(1), 6-11. http://dx.doi.org/10.12691/jaem-2-1-2

Sharon, C., Furugoh, S., Yamakido, T., Ogawa, H. I., \& Kato, Y. (1998) Purification and characterization of a lipase from Pseudomonas aeruginosa KKA-5 and its role in castor oil hydrolysis. Journal of Industrial Microbiology and Biotechnology, 20(5), 304-307. http://dx.doi.org/10.1038/sj.jim.2900528

Silveira, E., Marques, P. P., Macedo, A. C., Mazzola, P. G., Porto, A. L. F., \& Tambourgi, E. B. (2011). Decolorization of industrial azo dye in an anoxic reactor by PUF immobilized Pseudomonas oleovorans. Journal of Water Reuse and Desalination, 1(1), 18-26. http://dx.doi.org/10.2166/wrd.2011.030

Song, J. H., Jeon, C. O., Choi, M. H., Yoon, S. C., \& Park, W. (2008) Polyhydroxyalkanoate (PHA) production using waste vegetable oil by Pseudomonas sp. strain DR2. Journal of Microbiology and Biotechnology, 18(8), 1408-1415.

Summers, R. M., Mohanty, S. K., Gopishetty, S., \& Subramanian, M. (2015) Genetic characterization of caffeine degradation by bacteria and its potentia applications. Microbial biotechnology, 8(3), 369-378 http://dx.doi.org/10.1111/1751-7915.12262

Supakdamrongkul, P., Prasong, P., \& Gitram, K. (2014) Production and characterization of thermostable alkaline lipase from a newly isolated Pseudomonas sp. HCU2-1 suitable for detergent formulation. Proceedings of the 40th Congress on Science and Technology of Thailand.

Tarangini, K., \& Mishra, S. (2013). Production, characterization and analysis of melanin from isolated marine Pseudomonas sp. using vegetable waste. Research Journal of Engineering Sciences, 2(5), 40-46.

Thavasi, R., Nambaru, V. S., Jayalakshmi, S., Balasubramanian, T., \& Banat, I. M. (2011). Biosurfactant production by Pseudomonas aeruginosa from renewable resources. Indian journal of microbiology, 51(1), 30-36. http://dx.doi.org/10.1007/s12088-011-0076-7.

Thijsse, G. J. E., \& Van der Linden, A. C. (1961). Iso-alkane oxidation by a Pseudomonas Part I.-Metabolism of 2-methylhexane. Antonie van leeuwenhoek, 27(1), 171-179. http://dx.doi.org/10.1007/BF02538437

Timmis, K. N. (2010). Handbook of Hydrocarbon and Lipid Microbiology. Springer-Verlag Berlin Heidelberg.
Tripathi, A. D., Yadav, A., Jha, A., \& Srivastava, S. K. (2012). Utilizing of sugar refinery waste (cane molasses) for production of bio-plastic under submerged fermentation process. Journal of Polymers and the Environment, 20(2), 446-453. http://dx.doi.org/10.1007/s10924-011-0394-1

Umar, H., Umar, A., Ujah, U. J., Hauwa, B., Sumayya, B. I., Shuaibu M. Yakubu M.S. (2013). Biodegradation of waste lubricating oil by bacteria isolated from the soil. IOSR Journal of Environmental Science, Toxicology and Food Technology, 3 (6), 62-67.

van Beilen, J. B., Kingma, J., \& Witholt, B. (1994). Substrate specificity of the alkane hydroxylase system of Pseudomonas oleovorans GPo1. Enzyme and microbial technology, 16(10), 904-911. http://dx.doi.org/10.1016/0141 0229(94)90066-3

Vandana, P., \& Peter, J. K. (2014) Application of partially purified laccases from Pseudomonas fluorescens on dye decolourization. International Journal of Advanced Technology in Engineering and Science, 2(8), 317-327.

van Ravenswaay Claasen, J. C., \& Van der Linden, A. C. (1971). Substrate specificity of the paraffin hydroxylase of Pseudomonas aeruginosa. Antonie van Leeuwenhoek, 37(1), 339-352. http://dx.doi.org/10.1007/BF02218504

Venkatesh, N. M., \& Vedaraman, N. (2012). Remediation of soil contaminated with copper using rhamnolipids produced from Pseudomonas aeruginosa MTCC 2297 using waste frying rice bran oil. Annals of microbiology, 62(1), 85-91 http://dx.doi.org/10.1007/s13213-011-0230-9

Wang, H. H., Yin, B., Peng, X. X., Wang, J. Y., Xie, Z. H., Gao, J., \& Tang, X. K. (2012). Biodegradation of nicotine by newly isolated Pseudomonas sp. CS3 and its metabolites. Journal of applied microbiology, 112(2), 258-268. http://dx.doi.org/10.1111/j.1365-2672.2011.05208.x

Wang, S. N., Liu, Z., Tang, H. Z., Meng, J., \& Xu, P. (2007). Characterization of environmentally friendly nicotine degradation by Pseudomonas putida biotype A strain S16. Microbiology, 153(5), http://dx.doi.org/10.1099/mic.0.2006/005223-0

Wang, W., Xu, P., \& Tang, H. (2015). Sustainable production of valuable compound 3-succinoyl-pyridine by genetically engineering Pseudomonas putida using the tobacco waste. Scientific reports, 5, 16411. http://dx.doi.org/10.1038/srep16411

Ward, P. G., Goff, M., Donner, M., Kaminsky, W., \& O'Connor, K. E. (2006). A two step chemo-biotechnological conversion of polystyrene to a biodegradable thermoplastic. Environmental science \& technology, 40(7), 2433-2437. http://dx.doi.org/10.1021/es0517668

Williams, P. T. (2005). Waste treatment and disposal. Wiley: Chichester.

Yu, C. L., Louie, T. M., Summers, R., Kale, Y., Gopishetty, S., \& Subramanian, M. (2009). Two Distinct Pathways for Metabolism of Theophylline and Caffeine Are Coexpressed in Pseudomonas putida CBB5 . Journal of Bacteriology,191(14), 4624-4632. http://doi.org/10.1128/JB.00409-09

$\mathrm{Yu}, \mathrm{H} .$, Tang, H., \& Xu, P. (2014). Green strategy from waste to value-addedchemical production: efficient biosynthesis of 6-hydroxy-3-succinoyl-pyridine by an engineered biocatalyst. Scientific reports, 4 http://dx.doi.org/10.1038/srep05397

Zhang, Z., Hou, Z., Yang, C., Ma, C., Tao, F., \& Xu, P. (2011). Degradation of nalkanes and polycyclic aromatic hydrocarbons in petroleum by a newly isolated Pseudomonas aeruginosa DQ8. Bioresource Technology, 102(5), 4111-4116. http://dx.doi.org/10.1016/j.biortech.2010.12.064

Zhong, W., Zhu, C., Shu, M., Sun, K., Zhao, L., Wang, C., ... \& Chen, J. (2010) Degradation of nicotine in tobacco waste extract by newly isolated Pseudomonas sp. ZUTSKD. Bioresource technology, 101(18), 6935-6941. http://dx.doi.org/10.1016/j.biortech.2010.03.142

Zollinger, H. (1987). Color chemistry synthesis properties and application of organic dyes and pigments. VCH New York. 